\title{
The Perils of Populist Radical Right Parties: The Case of the Bulgarian Attack Party
}

\author{
Tatiana P. Rizova ${ }^{1}$ \\ ${ }^{1}$ Department of Government, Christopher Newport University, USA \\ Correspondence: Tatiana P. Rizova, 1 Avenue of the Arts, Newport News, VA 23606, USA. Tel: 1-757-594-7971. \\ E-mail: tatiana.rizova@cnu.edu
}

Received: July 31, 2013 Accepted: September 2, 2013 Online Published: November 29, 2013

doi:10.5539/jpl.v6n4p160 URL: http://dx.doi.org/10.5539/jpl.v6n4p160

\begin{abstract}
Populist radical right parties, such as the Bulgarian Attack Party, sow the seeds of ethnic discord and rally around authoritarian policies for sustaining domestic order. Scholars studying these political parties have focused on examining their leaders' rhetoric, political messages, and electoral success, but have paid less attention to their effects on liberal democracy. This study assesses Attack's impact on Bulgarian liberal democracy. Analysis of data from the 2008 European Social Survey suggests that party preference does not affect liberal democratic values such as attitudes toward torture and immigrants, but does help us predict people's opinions on gay rights. None of Attack's legislative proposals to curtail minority rights in the Bulgarian National Assembly were approved. In spite of its image as an anti-establishment party, Attack's legislators supported Borisov's cabinet in several no confidence votes between 2009 and 2012. Overall, Attack has had little impact on Bulgaria's legislative and political process.
\end{abstract}

Keywords: Attack Party, Bulgaria, populism, radical right

\section{Introduction}

More than a decade ago, the Political Affairs Committee of the Council of Europe issued a report, which warned citizens and politicians about the proliferation of extremist parties and movements 'that encourage intolerance, xenophobia, and racism' and 'defend ideologies that are incompatible with democracy and human rights.' (Note 1) Proponents of liberal democracy feel rightful indignation at the flagrantly racist rhetoric adopted by the leaders of extremist right political parties. The problem of right-wing extremism throughout Europe has hardly subsided since 2000. In a recent statement, Márton Gyöngyösi, an MP of the Hungarian Jobbik party, declared that Hungarians should make a list of all Jews who live in the country, particularly those who occupy positions in the legislature and the government, for they pose a grave national security threat. (Note 2) A leader of Romania's New Generation Party stated that if he were to win the 2009 presidential elections, he would force all homosexuals in special ghettos (Bugaric, 2008).

Scholars have extensively researched these parties' origins, discourses, electoral strategies, and leadership styles (Betz, 2005; Eatwell, 2003; Fennema, 2005; Norris, 2005; Wodak, 2005). Numerous hypotheses have been propounded in an attempt to explain their popularity and variations in their electoral success in different political contexts (Eatwell, 2003; Mudde, 2004). Less attention has been paid, however, to the effects of these political parties on people's value systems, their participation in legislative processes, and their influence on their countries' political processes. The analyses that do address these parties' political effects provide excellent overview of the anti-liberal values reflected in the parties' rhetoric and official statements (Arter, 2010; Betz, 2005). Nevertheless, we still know too little about these parties' effect on legislation and the inclusion of their values into policy outcomes. Since these political parties emerged in Western Europe first, most of the literature features West European case studies and comparative analyses (Ignazi, 2003; Kitschelt, 2007; Mény \& Surel, 2002). Several studies of populist radical right parties (PRRPs) in Eastern and Central Europe offer insights on the differences between and within this party family in Western and Eastern Europe (Mudde, 2007; Mudde \& Rovira-Kaltwasser, 2012; Ramet, 1999; Todorov, 2007). Still, we have yet to explore their effects on liberal democracy. It is important to investigate these parties' effects in Central and Eastern Europe because the liberal foundations of new democracies are more vulnerable to the attacks of the far right than those of established democracies. This study 
examines the individual, institutional, and systemic effects of Bulgaria's PRRP - the Attack Party - between its formation in 2005 and the present.

Though Bulgarian voters have had their brush with right-wing political organizations and parties during the country's post-communist history, the first successful Bulgarian PRRP emerged in the 2005 parliamentary elections. Some radical right political parties did form immediately after the fall of communism. These include the Internal Macedonian Revolutionary Party (VMRO), the Zora Political Circle, the Bulgarian National Radical Party (BNRP), and others that were founded in the early 1990s (Ivanov \& Ilieva, 2005). Most of these parties do not boast impressive membership numbers, typically gain less than five per cent of the national vote in parliamentary elections, and have been irrelevant to the legislative process because of their extra-parliamentary status. BNRP, for instance, gained only 0.1 per cent of the vote in the 2001 parliamentary elections while the Zora Political Circle never contested parliamentary elections. Attack stands out, for it overcame the five per cent threshold in two consecutive parliamentary elections (2005 and 2009), and gained parliamentary representation in the last two National Assemblies.

Analysis of survey data from the 2008 European Social Survey suggests that people who voted for or identified with Attack were no more likely to hold beliefs that contradict liberal democratic principles than those who voted for or identified with other political parties. (Note 3) There is no conclusive evidence that the Attack Party bred or that its supporters and voters held illiberal beliefs based on the 2008 survey. A comprehensive examination of Attack's legislative proposals between 2005 and 2012 reveals that though a portion of them contained provisions that would have undermined liberal democratic principles, Attack lost the legislative battle on all of them. Bulgarian mainstream political parties shunned Attack and did not support any of its proposed laws or amendments to extant legislation. Mudde and Rovira-Kaltwasser (2012) have argued that PRRPs like Attack could potentially offer a corrective to some of the flaws of liberal democratic systems. Though Attack's rhetoric is replete with scathing criticism of the cabinets of Sergey Stanishev (2005-2009) and Boyko Borisov (2009-2013), the party's actions have belied its aggressive anti-government discourse. Attack failed to support multiple no confidence votes on Borisov's cabinet, and even backed out of votes it had formally endorsed. Its inaction undermines its raison d'être - to bring politics to the masses, involve them in policy making, and hold the government accountable for its policy failures. While the evidence revealing Attack's legislative and political disengagement contradicts Mudde and Rovira-Kaltwasser's theoretical proposition, it does not disprove their general argument.

\section{Brief History of the Attack Party}

Attack was founded by Volen Siderov, a former reporter at a right-wing Bulgarian daily publication (Monitor). Siderov and his supporters are notorious for stirring trouble between Bulgarians and ethnic Turks and Roma who represent Bulgaria's two largest minorities. Siderov cultivated popular support long before Attack's birth as a political formation. As the host of a cable talk show, entitled 'Attack,' he chastised Bulgaria's corrupt politicians and demanded public accountability for their political missteps. His broadcasts included impassioned discussions of the country's economic and social ills, which Siderov attributed to Bulgaria's ethnic minorities and greedy and incompetent politicians. (Note 4) When Siderov first stepped on the political scene as a mayoral candidate in Sofia in 2003, he already had a core group of supporters. In spite of his popularity as a TV persona, Siderov's first electoral attempt was disastrous. As a candidate of the historic agricultural party (BZNS), he received only 1,728 out of 1,069, 342 votes and his participation in these local elections did not merit too much media attention. (Note 5) Siderov launched his own political formation - the Attack Coalition - to participate in the 2005 parliamentary elections, which helped him seal a victory and secured his parliamentary seat. The Attack Coalition would later evolve and consolidate into a political party. Siderov's authoritarian presence in the newly-formed party spelled trouble during his second parliamentary term and prompted several of its legislators to join other political parties. Currently, Attack's parliamentary group consists of ten MPs, down from twenty-one MPs in 2009.

\section{Effects of the Attack Party on Bulgarian Liberal Democracy}

The present study assesses Attack's influence on Bulgaria's liberal democracy by examining whether it breeds or reflects people's illiberal beliefs, analysing its legislative impact, and evaluating its effect on the national political process. (Note 6) Though some authors have analysed Attack's origins (Genov, 2010; Ghodsee, 2008; Smrčková, 2009) and the profile of the Attack voter (Stefanova, 2009), to date no studies have focused on its effects on liberal democracy.

This study finds that while many of Attack's political views may be morally repugnant, so far the party has posed little threat to Bulgarian liberal democracy at the individual, institutional or systemic level. First, the study explores the effect of party affiliation and electoral support on several aspects of liberal democratic attitudes - an 
individual's support for torture and restrictive immigration policies, and lack of support for gay rights. Second, it assesses the legislative impact of the party by examining the type of legislation proposed by the party and evaluating the success of its legislative agenda. Third, it examines the party's political impact by analysing its involvement in Bulgaria's political processes.

Negative attitudes towards immigration and immigrant communities, ethnic and racial minorities, homosexuals, and any other 'outsiders' are a trademark of populist radical right political parties.

The classic enemy [of populist radical right parties] is the ethnic minority. Generally speaking, in Western Europe the archetypal group of the enemy within the state, outside the nation, is the immigrant community, whereas in Eastern Europe indigenous ethnic minorities are the usual suspects. That said, various West European populist radical right parties are also xenophobic towards nonimmigrant ethnic minorities, while an increasing number of Eastern European parties have started to target the still small recent immigrant communities. (Note 7)

Since Bulgaria has a very small number of immigrants, the ideal target of Attack Party's scathing rhetoric and animosity are the 'indigenous ethnic minorities' that Mudde is referring to. The most direct way of evaluating the effects of Attack on illiberal attitudes would be to analyse attitudes toward target groups such as ethnic minorities amongst those individuals who identify with Attack and vote for its candidates. (Note 8) Individuals who associate with a populist radical right party should be more prone to hold negative attitudes toward minority groups based on attributes such as ethnicity or sexual orientation. In the case of Bulgaria, such negativity would be displayed toward ethnic Turks, Roma and homosexuals. One would also expect that supporters of a populist radical right party would be less tolerant toward immigrants, and that intolerance will be exhibited in negative attitudes toward immigrant communities. Finally, individuals who identify with this type of political party are less likely to consider human rights protection an important political priority. These individuals are less likely to see value in honoring and protecting human rights, and may be more accepting of human rights abuses than individuals who identify with non-extremist political parties.

The study shows that voters who identified with the Attack Party or cast a vote for it in the 2005 elections were no more likely to support torture, restrictive immigration policies or oppose homosexuals' rights than voters who identified with or voted for other political parties. Second, while a good proportion of Attack's legislative proposals between 2005 and 2012 sought to undermine minority rights, and therefore had the potential to undermine liberal democracy, none of them received sufficient support on the legislative floor. Third, even though Attack's leader had vouched to help throw the rascal politicians out and hold them accountable for corruption and economic mismanagement, the party missed several opportunities to deliver on its promise. Its leader Siderov helped invoke several votes of no confidence on the government of Boyko Borisov, yet the members of his parliamentary group withdrew their support when the no confidence motions were brought to the legislative floor. The study concludes that Attack's legislative activity has not undermined Bulgarian liberal democracy. The party has failed to augment government accountability by bringing the corrupt elite to justice; hence, it is an anti-establishment political party in name only.

\section{The Perils of PRRPs and the Case of the Attack Party}

Scholars have defined populist radical right parties as those political parties whose political platforms stand on the following three pillars - nativism, nationalism, and populism (Mudde, 2007; Ramet, 1999). Mudde (2007: 16) defines nationalism as 'a political doctrine that strives for the congruence of the cultural and the political unit, i.e. the nation and the state, respectively.' Attack's rhetoric relies on references to the greatness of the Bulgarian nation and demonstrates its leader's pride in Bulgarian culture, history, and language. (Note 9) Nativism is defined as 'an ideology, which holds that states should be inhabited exclusively by members of the native group ("the nation") and that nonnative elements (persons and ideas) are fundamentally threatening to the homogenous nation-state' (Mudde, 2007: 19). Attack's leader's speeches are frequent displays of belligerence towards two main groups of people - ethnic Turks and the Roma minority. Populist political movements and parties are 'of the people but not of the system,' observes Taggart (Taggart, 1996: 32). Populism is 'an ideology that considers society to be ultimately separated into two homogeneous and antagonistic groups, 'the pure people' versus the 'corrupt elite', and which argues that politics should be an expression of the volonté générale (general will) of the people' (Mudde, 2004: 543). Siderov identifies ethnic Turks, Roma, and Jews as the bane of Bulgarian society. (Note 10) His speeches describe the chasm that divides the morally upright people and the debauched political elites and minority groups. Siderov has sought to maximize the popular appeal of his political party by making promises that will hardly ever be fulfilled and rely on an impractical political vision. (Note 11) 
The defining features of PRRPs present us with an interesting paradox. These parties' leaders argue that the rules of the political game should empower constituents by giving them full access to the decision-making process. Most decision-making should be performed through direct democracy, wherein citizens will have the ability to vote directly on almost all important pieces of legislation and make policy in national referenda and plebiscites. Whether this aspect of democracy is desirable or not is beyond the purview of the present study. What is clear, however, is that not all aspects of populist radical right political parties are detrimental to democratic principles by definition. (Note 12) The element of populist radical right parties that is inimical to liberal democracy is these parties' definition of the people. The people is defined as that group of individuals who constitute a country's nation, and in the case of multi-ethnic nation-states, the people would only include members of the majority ethnic group. Minority groups based on ethnicity, religious belief, language, sexuality, and race, among others, are excluded from the definition of the national group (Anastasakis, 2001: 17; Mudde, 2004: 543). In the case of Bulgaria, for instance, Attack considers ethnic Turks as outsiders. They do not belong to the Bulgarian national group, for they are Muslims rather than Orthodox Christians, they speak a language other than Bulgarian, and they are a constant reminder of a gloomy history of Ottoman oppression that nationalists refuse to leave behind. Since Turks are outsiders, they hardly deserve a say in Bulgarian politics. Roma people are marginalized and treated as personae non gratae. Attack's messages portray the Roma as the main culprits for the rise in crime levels, whereas ethnic Turks are treated as a scourge to Bulgarian cultural identity. Attack Party's leadership has organized several protests demanding that the government stamp out Roma criminal activity. Attack leaders have also been vocal in expressing their intolerance toward homosexuals and same-sex marriage. Their position on gay rights and marriage is consistent with the position of the Orthodox Church whose Patriarch has made public pronouncements against gay rights and gay parades. (Note 13)

Liberal democrats, unlike populist radical right parties, do not accept exclusionary policies. They embrace rather than marginalize or exclude social groups based on their members' physical traits, religious preferences, ethnic group, worldviews, and lifestyle choices. Liberal democrats promote moderation and condemn extremism. The ideas of exclusion and marginalization of minorities against the backdrop of the superiority and supremacy of the majority that motivate PRRPs do not mesh with the philosophical foundations of liberal democracy (Plattner, 2004: 108). In a liberal democracy, there is recognition of group differences, but these differences may not serve as motivation to sow social discord. There is a fundamental philosophical incompatibility of liberal democracy and radical right extremism, which is reflected in the views, rhetoric, and actions of the Attack Party, and exposes the vulnerability of Bulgarian liberal democracy.

Robert Dahl identified the two defining characteristics of democracy as participation and contestation. PRRPs are inimical to liberal democracy because they violate the principle of participation. No electoral democracy qualifies as a liberal democracy unless minority rights are well-protected and minorities have access to the political process. Mudde and Rovira-Kaltwasser (2012: 13) argue that a democratic system is 'a complex form of government based on the idea of political equality, and consequently, cannot allow a majority to deprive a minority of any of its primary political rights, since this would imply a violation of the democratic process.' This study focuses on three aspects of liberal democratic values and systems in order to test the effects of the Attack Party on Bulgarian liberal democracy - attitudes towards torture, immigrants of the same or different ethnic group as the majority, and homosexuals.

\subsection{Liberal Democracy and Attitudes toward Torture}

Granted, even liberal democratic systems apply torture under the most extreme circumstances, such as a tool of preventing terrorist attacks or to provide disincentives to those who are likely to engage in acts of terror. Nevertheless, there is a distinction between the theoretical incompatibility between liberal democracy and torture and the actual practice of torture in liberal democracies.

Torture should remain anathema to a liberal democracy and should never be regulated, countenanced, or covertly accepted in a war on terror. For torture, when committed by a state, expresses the state's ultimate view that human beings are expendable. This view is antithetical to the spirit of any constitutional society whose raison d'être is the control of violence and coercion in the name of human dignity and freedom. (Note 14)

If one were to countenance torture in principle, then, that would constitute an illiberal attitude. A government that practices torture will be violating civil liberties, and hence, the very principles of liberal democracy (Lukes, 2006: 15-16). 


\subsection{Liberal Democracy and Attitudes toward Homosexuals and Their Rights}

In a liberal democracy, at least theoretically, individuals enjoy equal treatment regardless of race, gender, or sexual orientation. Even if the majority of its constituents were to favor discrimination on the basis of these or other attributes, a government anchored in the principles of liberal democracy would have to uphold and protect individuals' rights to live as their conscience dictates, including marry a person of the same sex. As Claire Snyder has argued (2006: 9), "the liberal democratic state may not legitimately impose any particular "comprehensive" moral or religious doctrine on its citizens, but instead must leave individuals free to pursue their own vision of the good life by maintaining legal equality and protecting rights and liberties, including freedom of conscience, the right to privacy, and the right to marry.' A political party whose mission it is to encourage hatred toward homosexuals and actively deny them their rights compromises the foundations of a liberal democratic system.

Mudde and Rovira-Kaltwasser (2012: 18-21) add a new dimension to the debate about the inherent tension between populism and liberal democracy. Most contemporary scholars emphasize the negative effects of populism on representative democracy and democratic constitutional principles. Populist leaders of the ilk of Venezuela's Hugo Chavez or Bolivia's Evo Morales are frequently seen in negative light and little attention has been paid to studying the possible advantages of populism. Mudde and Rovira-Kaltwasser list six possible positive effects of populism, in which populism serves as a corrective rather than a menace to democracy. The authors suggest that populism could have a positive effect on liberal democracy, for it could 'increase democratic accountability' (2012: 21). Parliamentary and semi-presidential democracies rely on the constitutional use of votes of no confidence, which allow legislators to hold their executive accountable for its political performance. A PRRP without any representation in the executive, such as Attack, would probably see no confidence votes as an opportunity to increase government accountability. It would also lobby for the frequent use of referendums as a means of increasing citizen participation in the political process. The last part of the present study assesses Attack's role in seeking government accountability for perceived political and policy failures.

\section{Theoretical Propositions about the Perils of PRRPs}

The leaders of PRRPs are notorious for their incendiary rhetoric. Attack's leader Volen Siderov, for instance, has been the chief instigator of multiple public protests targeting Bulgaria's ethnic minorities. On 20 May 2011 Siderov and members of his party instigated a protest in front of the main mosque in the center of Sofia. They assaulted people who were praying in front of the mosque by pulling their prayer rugs and shouting invectives against the ethnic Turkish population such as 'Turks, get out!' Attack followers have participated in marches denouncing the right of homosexuals to organize and participate in public gay parades. More recently Attack has also organized protests against the rise of crimes committed by members of the Roma minority.

Attack's rhetoric and public protests could sour relations between the majority and minority ethnic groups, pit them against each other, and breed resentment against minorities in the minds of majority group members. Populist radical right parties such as Attack, therefore, are capable of undermining the foundations of liberal democracy through their rhetoric and public actions. One of the pillars of liberal democracy is tolerance toward members of minority groups. Whenever a political party caters only to the needs and wishes of the majority to the detriment of minority groups, liberal democratic principles are compromised. Individuals who identify with Attack or vote for it are more likely to exhibit intolerance toward minorities such as homosexuals, ethnic minorities, and immigrants. Such individuals are also more likely to tolerate human rights violations such as the use of torture by agents of the state.

In order to test the effects of Attack on liberal democracy, I draw on data in the 2008 European Social Survey (http://ess.nsd.uib.no/). The European Social Survey is a biennial social values survey conducted in more than 30 European countries. I rely on the data from the $4^{\text {th }}$ round of surveys, which covers the period following the 2005 parliamentary elections in Bulgaria. The Attack Party participated in these parliamentary elections as a member of an electoral coalition because the Bulgarian courts denied it registration as a political party.

One way in which we can gauge Attack's political presence in the life of Bulgarian people is by examining people's voting behavior, their own perception of how closely their values are reflected by Attack's political platform, and their choice to become affiliated with it. Voter choice can be operationalized as a nominal-level variable (voted for Attack or not). Voter membership can be operationalized as a nominal-level variable (membership in Attack or another political party). Personal identification with Attack can be measured at the nominal level (feel closest to Attack or another political party). Party membership levels in Bulgaria are extremely low, and hence there are too few members to draw any reliable conclusions. There were 2,093 respondents surveyed in the 2008 EES survey and only 137 declared that they held formal membership in a political party. Only five of these 137 stated that they were affiliated with Attack. Therefore, the two explanatory variables I will 
consider are voter preference and voter identification, both of which are measured at the nominal level. There are several variables in the ESS 2008 dataset that can be used as potential measures of the extent to which individuals' views reflect liberal democratic values. These are attitudes toward immigrant groups, opinions on the issue of torture, and positions on gay rights. The survey questionnaire contained two questions evaluating respondents' opinions on immigration policies. The first question probed respondents' opinions on immigration from the same ethnic majority group, while the second evaluated opinions about immigration of people from a different ethnic or racial group. All of the dependent variables are measured at the ordinal level. Appendix A provides information about all variables included in the analysis. I conducted multiple tests with and without controls that measured the association between the causal and dependent variables. Since all causal variables are measured at the nominal level, I have relied on chi-square tests and report asymmetrical measures of association such as Cramer's V and Lambda $(\lambda)$. The following hypotheses are general and may be applied to the case of any populist radical right political party, not just the Attack Party. The study will only present tests of these hypotheses based on the data from Bulgaria.

Hypothesis 1a: Individuals who voted for a populist radical right political party are more likely to support restrictive immigration policies toward immigrants of the same ethnicity than those who did not.

Hypothesis 1b: Individuals who voted for a populist radical right political party are more likely to support restrictive immigration policies toward immigrants from a different ethnicity that those who did not.

Hypothesis 2: Members of a populist radical right political party are more likely to support restrictive immigration policies than non-members.

Hypothesis 3: Individuals who identify with a populist radical right political party are more likely to support restrictive immigration policies than those who do not.

Hypothesis 4: Individuals who voted for a populist radical right political party are more likely to support torture than those who did not.

Hypothesis 5: Members of a populist radical right political party are more likely to support torture than non-members.

Hypothesis 6: Individuals who identify with a populist radical right political party are more likely to support torture than those who do not.

Hypothesis 7: Individuals who voted for a populist radical right political party are less likely to support gay rights than those who did not.

Hypothesis 8: Members of a populist radical right political party are less likely to support gay rights than non-members.

Hypothesis 9: Individuals who identify with a populist radical right political party are less likely to support gay rights than those who do not.

Due to the low party membership numbers in Bulgaria, it is impossible to assess the effects of party membership on liberal democratic values. Hence, the study does not present tests of hypotheses 2, 5, and 8 . These tests, however, should be possible in other political contexts where membership numbers are much higher and membership data is available. The value of these hypotheses is that they will help us assess how voter support and identification with a populist radical right party are likely to affect the consistency of individuals' worldviews with liberal democratic values.

\section{Summary of Results and Discussion}

I performed chi-square tests on the following hypotheses $-1 \mathrm{a}, 1 \mathrm{~b}, 3,4,6,7$ and 9 . The only hypotheses that were supported by the evidence drawn from the 2008 ESS dataset were hypothesis 7 and 9. Knowing the political party an individual chose to vote for or feels closest to does not help us predict whether that individual supports restrictive immigration policies or the use of torture as a tool of extracting information. Party preference, however, does help us predict attitudes toward gay rights. The Cramer's V statistics in both chi-square tests of hypothesis 7 and 9 were statistically significant at the 0.000 level. The results also reveal that there is no statistically significant distinction between those individuals who prefer Attack and those who prefer another political party on any of the issues that tap into liberal democratic attitudes. At the individual level, there is no reason to conclude that preference for the Attack Party undermines individuals' liberal democratic values. 
Table 1. Cross-tabulation of party identification and attitudes toward gay rights

\begin{tabular}{lllllllllllllllll}
\hline \multicolumn{10}{c}{ Which political party do you feel closer to? } \\
\hline & BSP & BND & VMRO & GERB & DPS & DSB & BZNS & NDSV & Attack & Novo & RZS & Evroroma & SDS & SSD \\
& & & & & & & & & & & & & Vreme & & & \\
\hline Agree* & $39.2 \%$ & $0 \%$ & $70 \%$ & $56 \%$ & $21.6 \%$ & $56.8 \%$ & $30 \%$ & $64.3 \%$ & $52.6 \%$ & $66.7 \%$ & $57.1 \%$ & $100 \%$ & $56.2 \%$ & $0 \%$ & $(10 \%$ \\
& $(120)$ & $(0)$ & $(7)$ & $(141)$ & $(22)$ & $(21)$ & $(3)$ & $(9)$ & $(51)$ & $(2)$ & $(4)$ & $(1)$ & $(45)$ & $(0)$ \\
\hline Neither* & $14.7 \%$ & $0 \%$ & $0 \%$ & $17.1 \%$ & $34.3 \%$ & $27 \%$ & $20 \%$ & $21.4 \%$ & $15.5 \%$ & $0 \%$ & $28.6 \%$ & $0 \%$ & $16.2 \%$ & $0 \%$ \\
& $(45)$ & $(0)$ & $(0)$ & $(43)$ & $(35)$ & $(10)$ & $(2)$ & $(3)$ & $(15)$ & $(0)$ & $(2)$ & $(0)$ & $(13)$ & $(0)$ \\
\hline Disagree* & $46.1 \%$ & $100 \%$ & $30 \%$ & $27 \%$ & $44.1 \%$ & $16.2 \%$ & $50 \%$ & $14.3 \%$ & $32 \%$ & $33.3 \%$ & $14.3 \%$ & $0 \%$ & $27.5 \%$ & $100 \%$ \\
& $(141)$ & $(2)$ & $(3)$ & $(68)$ & $(45)$ & $(6)$ & $(5)$ & $(2)$ & $(31)$ & $(1)$ & $(1)$ & $(0)$ & $(22)$ & $(1)$ \\
\hline & $100 \%$ & $100 \%$ & $100 \%$ & $100 \%$ & $100 \%$ & $100 \%$ & $100 \%$ & $100 \%$ & $100 \%$ & $100 \%$ & $100 \%$ & $100 \%$ & $100 \%$ & $100 \%$ \\
& $(306)$ & $(2)$ & $(10)$ & $(252)$ & $(102)$ & $(37)$ & $(10)$ & $(10)$ & $(97)$ & $(3)$ & $(7)$ & $(1)$ & $(80)$ & $(1)$ \\
\hline
\end{tabular}

*Do you agree or disagree with the following statement: 'Gays and lesbians should be free to live life as they wish to.'

$\lambda=0.103(\mathrm{p}=0.005)$, Cramer's V=0.216 ( $\mathrm{p}=0.000)$ Political parties: Bulgarian Socialist Party (BSP), Bulgarian New Democracy (BND), Internal Macedonian Revolutionary Organization (VMRO), Citizens for European Development of Bulgaria (GERB), Bulgarian National Agricultural Union (BZNS), National Movement Symeon II (NDSV), Order, Law, and Justice (RZS), Union of Democratic Forces (SDS), Union of Free Democrats (SSD).

Several important points are in order. First, it is possible that the tests produced statistically insignificant results because Attack had not had the chance to influence Bulgarian voters' attitudes on issues such as immigration and torture. Siderov had been in the public eye long before Attack's emergence as a political party and had gained notoriety with his impassioned nationalist speeches that promoted racism and xenophobia. Nevertheless, the political party itself did not present a fully-fledged nationalist, anti-minority, xenophobic platform until it competed in the 2005 elections. Second, as previous studies of Bulgarian voters' electoral behavior suggest, many voters gravitated toward the Attack Party for reasons other than its nationalist messages. The most comprehensive analysis of Attack's voters argues that citizens were drawn to the party because they saw it as an alternative to the mainstream political parties, which had failed to deliver economic progress for large segments of the Bulgarian population.

The radical-right vote may be regarded as a reaction against the mainstream party elite administering the post-communist transition, rather than as an outcome of the transition itself. Party-specific influences affected the motivations of individual categories of voters - blue-collar workers, older voters, and medium-education cohorts in the large cities, as well as voters sharing centrist ideology, lower levels of political trust, and ethnocentrism - to vote for Attack despite the lack of ideological proximity with the party. (Note 15)

Third, one of the dependent variables used in the study reflects attitudes toward immigration issues rather than ethnic minority groups. Bulgaria does not have large immigrant communities. It is possible that Attack Party's voters and supporters do not view immigrants as a threat because immigration is not considered a problem in Bulgaria and it has little real economic impact on Bulgarian citizens. (Note 16) Therefore, while Attack's supporters may not display open animosity toward immigrant groups, this does not suggest that they are not resentful toward ethnic minorities.

\section{The Legislative Perils of PRRPs}

In this section, I study the effects of the Attack Party on the Bulgarian legislative process. One would expect that a PRRP is more likely to propose legislation that is detrimental to minority groups and jeopardizes their civic rights than a mainstream political party. The Attack Party has been able to win a handful of parliamentary seats in the $40^{\text {th }}$ and $41^{\text {st }}$ Bulgarian National Assembly, but because it lacks coalition potential, it has not participated in the executive. I have examined all pieces of legislation that Attack Party's members of parliament have proposed between 2005 and 2012 and analyzed these legislative proposals that reflect the nationalist, populist, and nativist values of the party. To date the legislative impact of the party has been negligible. None of the legislative proposals 
that would have undermined minority rights were approved on the legislative floor. Table 2 presents a selection of legislative proposals put forward by Attack to the $40^{\text {th }}$ and $41^{\text {st }}$ Bulgarian National Assembly.

Table 2. Selection of attack's legislative proposals submitted to the $40^{\text {th }}$ and $41^{\text {st }}$ national assembly (2005 present)

\begin{tabular}{|c|c|c|}
\hline Law or Amendment & $\begin{array}{l}\text { Details of the proposal and } \\
\text { Elements of } \\
\text { Nativism (N) } \\
\text { Nationalism (NA) } \\
\text { Populism (P) }\end{array}$ & Approved by the Legislature? \\
\hline Amendment to Penal Code & $\begin{array}{l}\text { Prison penalty for desecrating } \\
\text { national symbols (NA) }\end{array}$ & No \\
\hline Amendment to Electoral Law & $\begin{array}{l}\text { Monetary fines for constituents } \\
\text { who refuse to vote } \\
\text { Expatriates not eligible to vote } \\
\text { (NA) }\end{array}$ & No \\
\hline Amendment to Citizenship Law & Abolish dual citizenship (N, NA) & No \\
\hline $\begin{array}{l}\text { Amendment to Law on Radio and } \\
\text { Television }\end{array}$ & $\begin{array}{l}\text { Eliminate news programming in } \\
\text { Turkish }(\mathrm{N})\end{array}$ & No \\
\hline Amendment to Law on Referenda & $\begin{array}{l}\text { Increase the use of referendum } \\
\text { voting }(\mathrm{P})\end{array}$ & No \\
\hline $\begin{array}{l}\text { Law on Volunteer Security } \\
\text { Organizations }\end{array}$ & $\begin{array}{l}\text { Encourage the formation of } \\
\text { citizen-led security organizations } \\
\text { to fight crime }(\mathrm{N})\end{array}$ & No \\
\hline
\end{tabular}

Even though Attack Party representatives advanced multiple legislative proposals that would undermine the rights and liberties of Bulgarian citizens and ethnic minorities, its nationalist and nativist legislative agenda did not meet the approval of Bulgarian parliamentarians. To date, none of the legislative proposals has been approved by the Bulgarian Parliament. Attack has received resistance on the legislative floor and has been shunned by members of most major political parties in the Bulgarian legislature. Bulgarian political parties have formed a cordon sanitaire around the Attack Party. Their treatment of Attack is similar to the treatment that the Belgian Vlaams Blok, the Hungarian Justice and Life Party (MIÉP), and other political parties have received from other parliamentary actors in their respective political systems (Mudde 2007: 197).

\section{The Failure of the Attack Party to Exert Positive Influence on Bulgarian Liberal Democracy}

The discussion of Attack's inability to influence the legislative process because of its isolation demonstrates that most Bulgarian political parties disavow it as a potential coalition partner. Its lack of legislative weight is not difficult to explain; the party's numbers in parliament are small and its ideas too extreme and unpopular among mainstream political parties. In addition, the party's parliamentary group has been dwindling in size due to leadership squabbles that caused irreparable internal schisms. Regardless of its small size, however, the party is not devoid of political influence. The effective number of parties in the Bulgarian Parliament was 4.8 and 3.34 in the $40^{\text {th }}$ and $41^{\text {st }}$ National Assembly, respectively. (Note 17) Though unsuccessfully, Attack has acted as an anti-system party on the legislative floor. However, it has failed to act as an anti-system party in its interactions with the Bulgarian executive. An in-depth examination of Attack's positions and votes on all no confidence motions between 2005 and 2012 reveals the following patterns. First, Attack's constant criticism of the triple coalition led by the leader of the Bulgarian Socialist Party Sergey Stanishev was congruent with its behavior on the legislative floor. Attack signed and voted in favor of all seven no confidence motions invoked against Stanishev's government between 2005 and 2009. Second, Attack's rhetoric regarding the actions of Prime Minister Boyko Borisov's government has not been consistent with its actions on the legislative floor. While Attack helped invoke several no confidence votes on Borisov's government, Siderov quickly withdrew his party's support once these no 
confidence votes reached the legislative floor. Table 3 presents detailed information about Attack's positions on all no confidence votes invoked against two cabinets between 2005 and 2012.

Table 3. Attack's positions on 12 no confidence votes (2005-2012)

\begin{tabular}{|c|c|c|c|}
\hline $\begin{array}{l}\text { Date of No Confidence } \\
\text { Vote }\end{array}$ & Rationale & Attack's Position & Result \\
\hline 11 April 2006 & $\begin{array}{l}\text { Stanishev's failure to } \\
\text { respond to the 2005-06 } \\
\text { floods }\end{array}$ & Initiated by Attack & Unsuccessful \\
\hline 22 February 2007 & $\begin{array}{l}\text { Failure of education } \\
\text { policy }\end{array}$ & $\begin{array}{l}\text { Initiated by } 55 \text { MPs } \\
\text { including Attack }\end{array}$ & Unsuccessful \\
\hline 15 October 2007 & $\begin{array}{l}\text { Failure of education } \\
\text { policy }\end{array}$ & $\begin{array}{l}\text { Initiated by } 64 \text { MPs } \\
\text { including Attack }\end{array}$ & Unsuccessful \\
\hline 14 February 2008 & $\begin{array}{l}\text { Corruption and misuse } \\
\text { of European funds }\end{array}$ & Supported by Attack & Unsuccessful \\
\hline 8 April 2008 & $\begin{array}{l}\text { Criminal networks' links } \\
\text { to the government }\end{array}$ & $\begin{array}{ll}\text { All Attack } & \text { MPs } \\
\text { supported the } & \text { no } \\
\text { confidence vote } & \end{array}$ & Unsuccessful \\
\hline 30 July 2008 & $\begin{array}{lr}\text { Squandering } & \text { of } \\
\text { European } & \text { accession } \\
\text { funds } & \end{array}$ & $\begin{array}{l}\text { Initiated by opposition } \\
\text { MPs including Attack }\end{array}$ & Unsuccessful \\
\hline 18 February 2009 & $\begin{array}{l}\text { Complete failure of } \\
\text { governance }\end{array}$ & $\begin{array}{l}11 \text { Attack MPs } \\
\text { supported the vote of no } \\
\text { confidence }\end{array}$ & Unsuccessful \\
\hline 6 October 2010 & $\begin{array}{l}\text { Failure of health care } \\
\text { policy }\end{array}$ & $\begin{array}{l}\text { All of Attack's MPs } \\
\text { voted against the vote of } \\
\text { no confidence }\end{array}$ & Unsuccessful \\
\hline 10 June 2010 & $\begin{array}{l}\text { Failure of the } \\
\text { government's policy } \\
\text { tackling the economic } \\
\text { crisis }\end{array}$ & $\begin{array}{l}\text { Attack's MPs did not } \\
\text { vote and saved the } \\
\text { cabinet }\end{array}$ & Unsuccessful \\
\hline 18 July 2011 & $\begin{array}{l}\text { Vote of no confidence on } \\
\text { Bulgarian interior } \\
\text { minister Tsvetanov }\end{array}$ & Attack MPs did not vote & Unsuccessful \\
\hline 19 April 2012 & $\begin{array}{l}\text { Failure of energy policy } \\
\text { caused by cancelling } \\
\text { plans to begin nuclear } \\
\text { power plant construction }\end{array}$ & $\begin{array}{l}\text { Attack endorsed the } \\
\text { motion to initiate vote of } \\
\text { no confidence, but its } \\
\text { MPs did not vote for it }\end{array}$ & Unsuccessful \\
\hline 19 July 2012 & $\begin{array}{l}\text { Failure of judicial reform } \\
\text { and internal security }\end{array}$ & $\begin{array}{l}\text { Attack MPs did not } \\
\text { participate in the vote }\end{array}$ & Unsuccessful \\
\hline
\end{tabular}

\section{Conclusion}

In this study I examine the effects of Bulgaria's populist radical right political party - Attack - on Bulgarian liberal democracy at the individual, institutional, and systemic level. I use three attitudinal variables as a measure of liberal democratic values - opinions about torture, immigration policy, and gay rights. In a liberal democracy, individuals will have little tolerance for torture, will be open-minded on immigration policy, and will exhibit more tolerance toward homosexuals. My findings indicate that there is no evidence that party electoral preference and party identification affect people's attitudes toward torture and immigration policy. Party preference and 
identification do help us predict attitudes toward gay rights. However, Attack Party supporters are far more tolerant toward homosexuals than the supporters of other political parties such as the agricultural party (BZNS) and the party of Bulgaria's ethnic Turks (DPS). Moreover, the levels of tolerance toward homosexuals that Attack's supporters demonstrate is not significantly different from the levels of tolerance shown by supporters of more socially progressive mainstream political parties such as Union of Democratic Forces (SDS) and the National Movement Symeon the Second (NDSV). After examining all legislative proposals that Attack's parliamentarians submitted for review to the $40^{\text {th }}$ and $41^{\text {st }}$ Bulgarian National Assembly, I found that all proposed legislation, including legislation that would have been detrimental to ethnic minorities, was rejected on the legislative floor. Mainstream parties in the Bulgarian Parliament have successfully marginalized the Attack Party and have not allowed it to play a significant role in the formulation and implementation of legislation. Finally, Attack has not played an important role as an anti-systemic political party in its interactions with the executive. The party missed numerous opportunities to increase government accountability by failing to support motions of no confidence. The Attack Party's most powerful instrument remains its incendiary rhetoric. Most of the party's appeal, hence, is based on its leader's histrionics rather than the substance of its messages and its legislative and political weight.

\section{Acknowledgements}

The author would like to thank Marc P. Berenson, Olga Bertelsen, Bohdan Harasymiw, and other participants in the 2012 annual meeting of the Association for Slavic, East European, and Eurasian Studies and the 2013 annual convention of the Canadian Association of Slavists for their invaluable feedback and insights.

\section{References}

Anastasakis, O. (2001). Post-communist Extremism in Eastern Europe: The Nature of the Phenomenon. Studies in Ethnicity and Nationalism, 1(2), 15-26. http://dx.doi.org/10.1111/j.1754-9469.2001.tb00135.x

Arter, D. (2010). The Breakthrough of Another West European Populist Radical Right Party? The Case of the True Finns. Government and Opposition, 45(4), 484-504. http://dx.doi.org/10.1111/j.1477-7053.2010.01321.x

Betz, H. (2003). The Growing Threat of the Radical Right. In P. H. Merkl, \& L. Weinberg (Eds.), Right-Wing Extremism in the Twenty-First Century. London: Frank Cass.

Betz, H. (2005). Populism's Challenge to Liberal Democracy. In J. Rydgren (Ed.), Movements of Exclusion: Radical Right-Wing Populism in the Western World (New York: Nova Science Publishers).

Canovan, M. (1999). Trust the People! Populism and the Two Faces of Democracy. Political Studies, 47(1), 2-16. http://dx.doi.org/10.1111/1467-9248.00184

De Waele, J. (2008). Faces of Populism in Central and Eastern Europe. In H. Swoboda, \& J. Wiersma (Eds.), Democracy, Populism, and Minority Rights (PSE, Socialist Group in the European Parliament).

Eatwell, R. (2003). Ten Theories of the Extreme Right. In P. H. Merkl, \& L. Weinberg (Eds.), Right-Wing Extremism in the Twenty-First Century. London: Frank Cass.

Genov, N. (2010). Radical Nationalism in Contemporary Bulgaria. Review of European Studies, 2(2), 35-53.

Ghodsee, K. (2008). Left Wing, Right Wing, Everything: Xenophobia, Neo-totalitarianism and Populist Politics in Bulgaria. Problems of Post-Communism, 55(3), 26-39. http://dx.doi.org/10.2753/PPC1075-8216550303

Ignatieff, M. (2004). The Lesser Evil: Political Ethics in an Age of Terror. Princeton, N.J.: Princeton University Press.

Ignazi, P. (2003). Extreme Right Parties in Western Europe. Oxford: Oxford University Press. http://dx.doi.org/10.1093/0198293259.001.0001

Kitschelt, H. (2007). Growth and Persistence of the Radical Right in Post-Industrial Democracies: Advances and Challenges in Comparative Research. West European Politics, 30(5), 1176-1206. http://dx.doi.org/10.1080/01402380701617563

Lukes, S. (2006). Liberal Democratic Torture. British Journal of Political Science, 36(1). 1-16. http://dx.doi.org/10.1017/S0007123406000019

Mény, Y., \& Surel, Y. (2002) (Eds.). Democracies and the Populist Challenge. Basingstoke: Palgrave Macmillan.

Mudde, C. (2004). The Populist Zeitgeist. Government and Opposition, 39(4), 542-563. http://dx.doi.org/10.1111/j.1477-7053.2004.00135.x

Mudde, C. (2007). Populist Radical Right Parties in Europe. Cambridge: Cambridge University Press. http://dx.doi.org/10.1017/CBO9780511492037 
Mudde, C., \& Rovira-Kaltwasser, C. (Eds.). (2012). Populism in Europe and the Americas: A Threat or Corrective for Democracy? Cambridge: Cambridge University Press.

Norris, P. (2005). Radical Right: Voters and Parties in the Electoral Market. Cambridge: Cambridge University Press. http://dx.doi.org/10.1017/CBO9780511615955

Parliamentary Assembly of the Council of Europe. (2000). Recommendation 1438 'Threat posed to democracy by extremist parties and movements in Europe' (Strasbourg: Council of Europe). Retrieved from http://assembly.coe.int/Main.asp?link=/Documents/AdoptedText/ta00/EREC1438.htm

Plattner, M. (2004). A Skeptical Afterward. Journal of Democracy, 15(4), 106-110. http://dx.doi.org/10.1353/jod.2004.0069

Ramet, S. (Ed.). (1999). The Radical Right in Central and Eastern Europe Since 1989. University Park, PA: Pennsylvania State University Press.

Rupnik, J. (2006). Populism in East-Central Europe, IWM Post (94).

Rupnik, J. (2007). Is East-Central Europe Backsliding? From Democracy Fatigue to Populist Backlash. Journal of Democracy, 18(4), 17-25.

Rydgren, J. (2005). Is Extreme Right-wing Populism Contagious? Explaining the Emergence of a New Party Family. European Journal of Political Research, 44, 413-437. http://dx.doi.org/10.1111/j.1475-6765.2005.00233.x

Smrčková, M. (2009). Comparison of Radical Right-Wing Parties in Bulgaria and Romania: The National Movement of Ataka and the Great Romania Party. Central European Political Studies Review, 1, 48-65.

Snyder, C. R. (2006). Gay Marriage and Democracy: Equality for All. Lanham, Md.: Rowman \& Littlefield Publishers, Inc.

Stefanova, B. (2009). Ethnic Nationalism, Social Structure, and Political Agency: Explaining Electoral Support for the Radical Right in Bulgaria. Ethnic and Racial Studies, 32(9), 1534-1556. http://dx.doi.org/10.1080/01419870802541754

Taggart, P. (1996). The New Populism and the New Politics: New Protest Parties in Sweden in a Comparative Perspective. London: Macmillan.

Todorov, A. (2007). National Populism versus Democracy. Critique \& Humanism, 23(1), 81-95.

\section{Notes}

Note 1. Parliamentary Assembly of the Council of Europe, Recommendation 1438 (2000), "Threat posed to democracy by extremist parties and movements in Europe." http://assembly.coe.int/Main.asp?link=/Documents/AdoptedText/ta00/EREC1438.htm

Note 2. "Outrage at "Jewish list" Call in Hungary Parliament" www.reuters.com/article/2012/11/27/us-hungary-antisemitism-idUSBRE8AQ1BN20121127

Note 3. All data and relevant documentation from the survey are available to the public at the European Social Survey website: http://ess.nsd.uib.no/ess/

Note 4. Siderov and his political party have campaigned against Turkish membership in the European Union, declaring: 'If we sit and don't work like Bulgarian patriots, one day they [the Turks] will conquer us indeed.' http://www.novinite.com/view_news.php?id=104859

Note 5. Electoral data on the 2003 local elections was obtained from the website of the Bulgarian Central Electoral Commission: http://www.izbori2003.is-bg.net/tour1/rez/1-2246-2.html

Note 6. In the absence of data, which allows us to trace people's beliefs prior to and after Attack's emergence on the Bulgarian political stage, it is impossible to tell whether Attack breeds illiberal beliefs or merely reflects people's illiberal beliefs or perhaps even makes illiberal beliefs more radical. The data only allows us to test whether there are any substantial differences in the liberal belief structures of voters who support Attack and those who support other political parties.

Note 7. Cas Mudde, Populist Radical Right Parties in Europe, Cambridge: Cambridge University Press, 2007, p. 69. 
Note 8. Using people's attitudes toward ethnic minority groups will have been the ideal dependent variable in this analysis because negative attitudes toward minority ethnic groups are the trademark of East European populist radical right parties. The European Social Survey data that I use, however, does not contain data on attitudes toward ethnic minorities, so that makes it impossible to test the relationship between party identification, electoral support and attitudes toward ethnic minorities.

Note 9. While civic nationalism is not necessarily anti-democratic, ethnic nationalism tends to undermine liberal democracy. Since ethnic nationalism propounds an ethno-centric vision of the nation, it automatically excludes those citizens who do not belong to the in-group. See Vladimir Tismaneanu's discussion of the different brands of nationalism and the predominance of ethnic nationalism in Central and Eastern Europe, "Nationalism, Populism, and Other Threats to Liberal Democracy in Post-Communist Europe" The Henry Jackson School of International Studies, University of Washington, 1999, pp. 8-12.

Note 10. Othon Anastasakis has aptly described populist radical right parties' focus on international Jewry as the root of all evil. He presents a compelling argument that these parties' leaders propagate negative attitudes toward Jews even in countries without a Jewish population. Perhaps it is the very absence of a Jewish population that facilitates the spread of the myth of the Jewish aspiration to dominate the world. See Anastasakis, "Post-communist Extremism in Eastern Europe: The Nature of the Phenomenon" Studies in Ethnicity and Nationalism, Vol. 1, No. 2, 2001, p. 17.

Note 11. Attack's 20-point political program, for instance, includes the following populist ideas - withdrawal of Bulgaria from NATO and the prohibition of any foreign military bases on Bulgarian territory, the introduction of referendum voting for all issues that affect at least 10per cent of the people, the prohibition of foreign ownership of Bulgarian agricultural land property, and renegotiation of those chapters of EU membership that put Bulgaria at a disadvantage. The complete list of all 20 points is available in Bulgarian at http://www.ataka.bg/index.php?option=com_content\&task=view\&id=13\&Itemid=51

Note 12. Jacques Rupnik (2006) has presented a compelling argument that while populism is not antithetical to democracy, it does subvert liberalism by challenging essential facets of the rule of law.

Note 13. Siderov's nationalism is based on the idea that Bulgaria is a Slavic Christian Orthodox nation. The party's emblem bears the Orthodox cross as an important symbol of Eastern Christianity. The purpose of the religious symbol is to emphasize the religious dichotomy between Bulgarian Orthodox Christians and Turkish Muslims living in Bulgaria. Attack's emblem is depicted and its meaning is thoroughly explained at the following website: $\mathrm{http} / /$ www.ataka.bg/index.php?option=com_content\&task=view\&id=395\&Itemid=86

Note 14. Ignatieff, M. (2004), The Lesser Evil: Political Ethics in an Age of Terror (Princeton, N.J.: Princeton University Press), pp. 8-9.

Note 15. Stefanova, B. (2009), 'Ethnic Nationalism, Social Structure, and Political Agency: Explaining Electoral Support for the Radical Right in Bulgaria', Ethnic and Racial Studies, 32(9), p. 1539.

Note 16. Official statistics from the Bulgarian National Statistical Institute state that as of December 31, 2008, Bulgaria was home to 66,806 immigrants who came primarily from countries such as Ukraine, Moldova, the Former Yugoslav Republic of Macedonia, Russia, and Turkey. At the time, these people would have made up 0.9 per cent of the total population of Bulgaria Source: http://www.nsi.bg/otrasal.php?otr=19\&a1=367\&a2=375\#cont

Note $17 . \quad$ Michael Gallagher, Indices, http://www.tcd.ie/Political_Science/staff/michael_gallagher/ElSystems/Docts/ElectionIndices.pdf

\section{Copyrights}

Copyright for this article is retained by the author(s), with first publication rights granted to the journal.

This is an open-access article distributed under the terms and conditions of the Creative Commons Attribution license (http://creativecommons.org/licenses/by/3.0/). 


\section{Appendix A}

Variables

Appendix A lists all variables from the ESS 2008 survey that have been used in this study. The codes in brackets refer to the number of the survey question in the 2008 ESS Main Questionnaire (http://ess.nsd.uib.no/ess/round4/)

List of explanatory variables used in the study:

Party identification and party electoral support

Prtclabg: This nominal variable codes respondents' answers to the question "Which party do you feel closest to?" (B20b)

Ataka_close: This nominal variable has been derived from prtclabg and codes respondents' answers about which party they feel closest to with two values - 0 (do not feel closest to Attack) or 1 (feel closest to Attack).

Prtvtabg: This nominal variable codes respondents' answers to the question "Which party did you vote for in the last parliamentary election? In the case of Bulgaria that was the 2005 parliamentary election. (B12)

Prtvtabg_Ataka: This nominal variable has been derived from prtvtabg and codes respondents' answers about which party they voted for in the last election with two values - 0 (did not vote for Attack) and 1 (voted for Attack).

List of dependent variables used in the study:

\section{$\underline{\text { Attitudes toward homosexuals }}$}

Freehms: This ordinal variables codes respondents' reaction to the statement "Gays and lesbians are free to live life as they wish." The variable has 5 possible values that measure the strength of agreement or disagreement with this statement. (B31)

Freehms3: This ordinal variable is a recode of freehms and collapses the categories "strongly agree" and "agree" as well as "strongly disagree" and "disagree" into single categories. The variable has 3 possible values as opposed to 5 .

\section{Attitudes toward immigrants}

Imdfetn: This ordinal variable measures respondents' answers to the question "How many immigrants of a different race or ethnic group should be allowed into this country?" (B36)

Imsmetn: This ordinal variable measures respondents' answers to the question "How many immigrants of the same race or ethnic group as the majority of this country should be allowed?" (B35)

\section{Attitudes toward torture}

Trrtort: This ordinal variable codes respondents' reaction to the statement "Torture in this country is never justified even to prevent a terrorist attack." The variable has 5 possible values that measure the strength of agreement or disagreement with this statement. (C14)

Trrtort3: This ordinal variable is a recode of trrtort and collapses the categories "strongly agree" and "agree" as well as "strongly disagree" and "disagree" into single categories. The variable has 3 possible values as opposed to 5 values.

List of Relevant Questions Drawn from the Main Questionnaire ESS 2008

B12: Which party did you vote for in that election? [The respondents pick from a list of the main parties and can also provide the name of a political party that was not mentioned on the list, which goes in the category 'other.'

B20b: Is there a particular party you feel closer to than all the other parties? [If the respondent's answer is yes, then the respondent is prompted to reveal the name of the party he or she feels closer to.] 
B31: Using this card, please say to what extent you agree or disagree with each of the following statement: "Gay men and lesbians should be free to live their own life as they wish" (Agree strongly, Agree, Neither agree nor disagree, Disagree, Disagree strongly, (Don't know)

B35: Now, using this card, to what extent do you think [country] should allow people of the same race or ethnic group as most [country]'s people to come and live here? (Agree strongly, Agree, Neither agree nor disagree, Disagree, Disagree strongly, (Don't know)

B36: Now, using this card, to what extent do you think [country] should allow people of a different race or ethnic group from most [country]'s people to come and live here? (Agree strongly, Agree, Neither agree nor disagree, Disagree, Disagree strongly, (Don't know)

C14: Torturing a prisoner in a [country's] prison is never justified, even if it might provide information that could prevent a terrorist attack. (Agree strongly, Agree, Neither agree nor disagree, Disagree, Disagree strongly, (Don't know)

\section{Appendix B}

Statistical Results of Additional Chi-square Tests Based on the 2008 European Social Survey Data

Hypothesis
Younger people are more likely to
support gay rights than older
people.
Women are more likely to support
gay rights than men.
gay rights than men.

Younger people are more likely to tolerate immigrants than older people.

Women are more likely to tolerate immigrants than men.

Younger people are less likely to tolerate torture than older people.

Women are less likely to tolerate torture than men.
Independent variable: $g n d r$

Dependent variable: freehms3

Independent variable: agea 4

Dependent variables: Imdfetn and Imsmetn
Independent variable: agea4

Dependent variable: freehms3

Results
$\begin{aligned} & \text { Pearson's } \\ & (\mathrm{p}=0.000)\end{aligned}$
Cramer's V $=0.158(\mathrm{p}=0.000)$

Hypothesis supported

Pearson's chi-square $=6.178$

$(\mathrm{p}=0.046)$

Cramer's V=0.058 $(\mathrm{p}=0.046)$

\section{Hypothesis supported}

Pearson's chi-square $=37.781$

$(\mathrm{p}=0.000)$

Cramer's V=0.08 ( $\mathrm{p}=0.000)$

[DV: Imdfetn]

\section{Hypothesis supported}

Pearson's chi-square $=33.406$

$(\mathrm{p}=0.000)$

Cramer's V $=0.074(\mathrm{p}=0.000)$

[DV: Imsmetn]

\section{Hypothesis supported}

Independent variable: $g n d r$

Dependent variable: Imdfetn and Imsmetn

Independent variable: agea 4

Dependent variable: Trrtort3

Independent variable: $g n d r$

Dependent variable: Trrtort3
Statistical results not significant.

\section{Hypotheses rejected}

Statistical results not significant.

\section{Hypothesis rejected}

Statistical results not significant.

Hypothesis rejected 